\title{
Fire regimes during the last glacial
}

A.-L. Daniau ${ }^{1}$, S.P. Harrison ${ }^{1}$ and P.J. Bartlein ${ }^{2}$

${ }^{1}$ School of Geographical Sciences, University of Bristol, Bristol, BS8 1SS, UK

${ }^{2}$ Department of Geography, University of Oregon, Eugene, OR 97403, USA

Ms. For Quaternary Science Reviews, D-O Special Issue

Version: Oct $04^{\text {th }} 2009$ 


\begin{abstract}
Sedimentary charcoal records document changes in fire regime. We have identified 67 sites (30 sites with better-than millennial-resolution) which have records for some part of the last glacial to analyse changes in global fire regimes. Fire was consistently lower during the glacial than during the Eemian and Holocene. Within the glacial, Marine Isotope Stage (MIS) 3 is characterised globally by more fire than MIS 2. The signal for MIS 4 is less clear: there is more fire in the northern hemisphere and less fire in the southern hemisphere than during MIS 2 and 3. The records, most particularly records from the northern extratropics, show millennial-scale variability in fire regimes corresponding to the rapid climate changes associated with DansgaardOeschger (D-O) cycles. Most of the D-O cycles during the last glacial and all of the Heinrich Stadials are apparent in the composite global record of the high-resolution sites: fire increases during D-O warming events and decreases during intervals of rapid cooling. Our analyses show that fire regimes show a lagged response to rapid climate changes of ca 100-200 years in the case of D-O warming events, ca 0-100 years in the case of D-O cooling events and ca 200 years in the case of Heinrich Stadials. The strong climatic variability experienced during the glacial resulted in important changes in fire regimes even though the base level of biomass burning was less than today.
\end{abstract}




\section{Introduction}

Fire is the major cause of vegetation disturbance and helps to maintain vegetation diversity, productivity and nutrient cycling (Bond and Keeley, 2005; Bowman et al., 2009). The occurrence of fire is largely controlled by climatic conditions (e.g. van der Werf et al., 2008; Archibald et al., 2008), and thus provides a mechanism (along with disease mortality) through which vegetation can track climatic changes, but is also influenced by vegetation structure and productivity (Marlon et al., 2006; Lavorel et al., 2007; Archibald et al., 2008). Thus, climate changes will influence the fire regime both directly, through influencing lightning ignition, fuel moisture and the prevalence of fire weather, and indirectly through changes in vegetation type and productivity. Changes in fire regime in turn feedback on climate through their effects on the global carbon cycle, atmospheric chemistry, vegetation cover, and other physical and biological properties of the land surface such as albedo, soil water holding capacity and soil nutrient status (DeBano et al., 1998; Bowman et al., 2009). The interactions between climate, vegetation and fire regimes are complex, and can be difficult to disentangle under modern conditions when fire regimes are influenced by human activities. Charcoal produced during biomass burning episodes is relatively inert: charcoal records preserved in sedimentary sequences can therefore be used to reconstruct long-term changes in fire regime. Examining changing fire regimes on geological timescales provides an opportunity to disentangle the effects of climate and vegetation changes during intervals when human influence was negligible or non-existent.

The fire regime of a given environment is generally described in terms of the 
characteristic intensity, severity and frequency of fire and the magnitude of the resulting loss of biomass (Bond and Keeley, 2005; Hu et al., 2006). Although fire frequency can be reconstructed using high-resolution records and special techniques (see Whitlock and Bartlein, 2004), most palaeorecords only provide an indication of relative changes in biomass burning. Such changes are unlikely to have occurred without changes in other aspects of the fire regime, and here we assume that changes in biomass burning reflect changes in fire regime. Sedimentary charcoal records typically yield reconstructions of biomass burning on decadal- through centennial-tomillennial timescales (Haberle and Ledru, 2001; Carcaillet et al., 2002). The Global Palaeofire Working Group (http://www.bridge.bris.ac.uk/projects/QUEST_IGBP_Global_Palaeofire_WG) has created a database over 700 individual charcoal records worldwide (GCD_V2: Daniau and Tinner et al., in prep). Analyses of earlier versions of these data have focused on the past 21,000 years (see e.g. Power et al., 2008; Marlon et al., 2008; Marlon et al., 2009). Here we analyse longer records from the GPWG database to examine broadscale regional changes in fire regime during the last glacial (73.5-14.7 ka), in particular highlighting those high-resolution records that document the biomass burning response to rapid climate changes.

\section{Source and treatment of charcoal records}

The GPWG global charcoal database contains sedimentary charcoal records from both marine and terrestrial cores (Power et al., 2008). The database includes descriptive data (metadata) about both the sites and the charcoal samples, and detailed information on site chronology. Version 2 of the database (GCD-V2: Daniau and 
Tinner et al., in prep) contains charcoal records from nearly 700 sites; we have extracted the 67 records (11 marine and 56 terrestrial sites) that extend at least into Marine Isotope Stage 3 (MIS 3, > 27500 cal yr B.P.) for our analysis (Table 1, Fig. 1). Among these sites, 36 are of low resolution (less than one sample per ka for MIS 3 or MIS 4) and 31 of high resolution (more than 1 sample per ka). There are two cores from one of these high-resolution sites (Xere Wapo, Sites 722, 808) and we retained the single core (Site 722) that covered the longest interval for our analyses.

Charcoal records are obtained using several different methods (Power et al., 2008) and as a result are recorded as multiple different measurement types in the GCD. For our analyses, we use charcoal abundance or charcoal concentration. It would be possible to use the original charcoal measurements and the age models in the database to calculate charcoal influx through time. However, estimates of influx are strongly influenced by the quality of the age model and the number of age control or tie-points on some of the longer records is limited. For most of the individual sites used in our analyses, visual inspection of the record of last climatic cycle shows little difference between the records of abundance/concentration and those of influx in terms of temporal evolution; there are large differences however for the loess and marine records (Lijiayuan section: Site 109; Lingtai section: Site 110; Weinan section1: Site 111; MD95-2042: Site 542; MD04-2845: Site 849; ODP1078C: Site 1104; MD97-2140: Site 1105, see Tab. 1), most probably associated with rapid deposition events which cannot be resolved using the dating available. At such sites, we believe that the abundance or concentration data provide the more reliable estimate of changing fire regimes. We have used abundance or concentration data for the other sites for consistency. 
Charcoal values vary by orders of magnitude between and within sites; the data have to be standardized to facilitate comparisons between sites and through time. We have adopted a procedure (see Power et al., in press for a fuller description) that involves homogenization of the variance using a Box-Cox transformation, and then rescaling the transformed data as z-scores using a base period of $0.2-132$ ka so that all sites have a common mean and variance.

To place the changes in biomass burning during the glacial in context, we compare the long term signal to records for the preceding (Eemian) and subsequent Holocene interglacials. These comparisons were made using box plots of the transformed charcoal data from the 30 high-resolution sites (Table 1). The age limits for MIS 2 (27.8-14.7 ka), MIS $3(59.4-27.8 \mathrm{ka})$ and MIS 4 (73.5-59.4 ka) are defined in Sánchez-Goñi and Harrison (this volume); the limits for the Eemian were defined as 128-115 ka (following Kukla et al., 2002) and those for the Holocene as 11.7 ka to present (following Wolff et al., this volume).

Composite curves were constructed by fitting a lowess curve to the pooled transformed and rescaled data (e.g. Marlon et al., 2008), using a fixed window width, target points for which fitted values were obtained at 20-year intervals, and the tricube weight function with one "robustness iteration." In the earlier part of the time interval examined here the data become increasingly sparse, and so the window width was increased so that at least 30 data points contributed to each fitted value. The charcoal data were summarized using window half-widths of 400 years for comparison with the NGRIP oxygen-isotope record. The data were detrended by subtracting a lowess 
curve calculated using a 2000-year window to represent the longer-term variations in the slowly varying level of the charcoal. These particular parameter values were selected to avoid both oversmoothing, as would result from selecting a large window width, and undersmoothing, leading to a composite curve that was susceptible to influence of individual data points. Other combinations of parameter values produce essentially the same results and conclusions.

To characterize the typical variations in charcoal concentration around D-O warming events, D-O cooling events and Heinrich Stadials (HS), a superposed epoch analysis (SEA: Muscheler and Beer, 2006) was performed on the detrended charcoal data (Singh and Badruddin, 2006), aligning the charcoal deviations on the ages of the D-O warming events, and the start of HS as described in Sánchez-Goñi and Harrison (this volume) and Wolff et al. (this volume). The start of 19 most rapid cooling events was determined by inspection using the ages of the unsmoothed oxygen isotope data (see Table 2).

The data were summarized using 80 -year-wide "bins." This results in less noisy SEA plots, but has side effect of making the peaks more symmetrical about the event (defined as occurring at 0 years). The NGRIP oxygen-isotope data (Wolff et al., this volume) were summarized using 20-year-wide bins (the resolution of the data), and also using 80-year-wide bins, for comparison with the SEA of the charcoal data. Confidence intervals were calculated using a Monte-Carlo simulation (2000 replications) under the null hypothesis of random occurrence of events (Prager and Hoenig, 1992). The SEA composite or summary curves, formed in this application by the median values of the aligned segments of data that fall in a particular bin, show the aggregate or typical response of the variable being examined around the time of 
the key events. If there is a consistent response in a time series to some externally determined event, then this is shown in an SEA by the composite curve falling outside of the confidence band. This band shows the variability expected in the SEA composite curves when there is no consistent response of the time series to the event occurrence (as simulated by repeated generation of the same number of random events as in the record of interest).

\section{Broadscale changes in fire regimes between interglacial and glacial climates}

The spatial distribution of the charcoal sites is uneven (Fig. 1). There is only one high-resolution site from North America, four sites from southern Europe and three sites from the Chinese Loess Plateau. There are four from tropical South America, two sites from tropical Africa and seven sites from SE Asia and tropical Australasia. There is only one site from extratropical South America but seven sites from Australasia. Nevertheless, the coverage is sufficient to provide a preliminary picture of changes in fire regime during the last glacial.

Globally (Fig. 2a), as indicated by median values of abundance/concentration, biomass burning was higher during the Holocene and the Eemian than the last glacial. This pattern is characteristic of both the northern (Fig. 2b) and southern (Fig. 2c) hemispheres. Within the glacial, biomass burning in the northern hemisphere was lowest in MIS 2, and lower in MIS 3 than the relatively short interval of MIS 4 (Fig. 2b). In the southern hemisphere, biomass burning was highest in MIS 3, and MIS 4 has less biomass burning than MIS 2 (Fig. 2c). The box plots show that inter-site 
differences are less in the northern than the southern hemisphere, and hence the global differences between MIS 2, 3 and 4 reflect the northern hemisphere pattern.

These analyses show that biomass burning is generally high during interglacials and low during glacials, a result that is consistent with analyses of the past 21,000 years (Power et al., 2008) which show low biomass burning during the glacial and deglaciation and higher biomass burning during the Holocene. The higher global temperatures associated with MIS 3 (relative to those of MIS 4 and 2) are sufficient to produce an increase in biomass burning relative to MIS 2. There is less differentiation between MIS 3 and MIS 2 in the southern hemisphere, which is consistent with the fact that the maximum expression of cold, dry conditions occurs in the later part of MIS 3 and into MIS 2 (Allan and Lindsay, 1998; Vandergoes et al., 2005). Low levels of biomass burning in the southern hemisphere during MIS 4 are consistent with cold conditions. The high biomass burning in the northern hemisphere during MIS 4 is largely a reflection of the records from the Loess Plateau (Wang et al., 2005); European sites show fire regimes comparable to MIS 3.

There is considerable variation in the level of biomass burning around these median values. The amplitude of this variability, as shown by the 25 and 75 percentile limits on the box plots (Fig. 2), is a reflection of the extreme differences in fire regime within a given period. The variability in biomass burning at a global scale (Fig. 2a) is greater during the glacial than during the Eemian and Holocene. Within the glacial, MIS 3 shows the greatest absolute variability in fire regime. These patterns in the amplitude of variability are consistent with the marked millennial-scale climate variability during MIS 3 (Bond et al., 1993; North Greenland Ice Core Project 
Members, 2004) and the fact that climate variability within interglacials is more muted than during glacials (Overpeck and Webb, 2000).

\section{Millennial-scale variability in fire regimes during the glacial}

There are considerable differences in the patterns shown by individual records during the glacial (Fig. 3), and few sites show all of the features apparent in the global and hemispheric averages. Nevertheless, most of the records show millennial-scale variability at least for part of the glacial. The exceptions are Lake Pata (Site 432: Bush and Oliveira, 2006); Siberia-93-1 (Site 59: Mourguiart and Ledru, 2003), Xere Wapo C (Site 722: Stevenson and Hope, 2005) and Galway Tarn (Site 437: Vandergoes, unpub.) which show no fire during most of the length of the record - all these sites are sampled at high resolution and have sufficient dating control to document millennial-scale changes if they existed. Most of the records show that millennial-scale variability was more pronounced during MIS 3 than during MIS 2 and 4. The variability during MIS 3 is, in general, less apparent in the tropics than the extratropics (Fig. 3).

The millennial-scale variability expressed in certain charcoal records has been interpreted as a reflection of D-O climate variability through changes in fuel availability (see e.g. MD95-2042: Site 542, Daniau et al., 2007; MD04-2845: Site 849, Daniau et al., 2009). In these two sites, each of the Greenland Interstadials (GI) is marked by an increase in biomass burning contemporaneous with the expansion of forest; the reduction in biomass burning during Greenland Stadials (GS) is 
contemporaneous with the development of more open vegetation. Other sites show variability consistent with registration of several different D-O cycles (e.g. Valle di Castiglione: Site 846, Magri, 2008; Allom Lake: site 597, Donders et al., 2005). In these sites, the GI are also characterised by increased biomass burning and the GS by reduced biomass burning. However, many of the records display only a few peaks that appear to correlate to specific warming events (e.g. Lagaccione: site 845, Magri, 2008; Lingtai section: site 110, Wang et al., 2005). In some cases, the peaks occur earlier or later than expected (e.g. Lake Wangoom 20m Core: site 237, Edney et al., 1990; Caledonia Fen: site 859, Kershaw et al., 2007). The lack of coherence, as indeed the coherence of individual peaks, reflects lack of dating control particularly during the earlier parts of the records. Given this, it is not possible to be certain that the apparent reversal of the relationship between warmer phases of the D-O cycle and increased biomass burning shown by some records (see e.g. Native Companion Lagoon: site 819, Chalson, 1991; Lijiayuan section: site 109, Wang et al., 2005) is a reflection of geographic differences in registration or not.

We have constructed a composite global record of fire regime, based on all sites, through the last glacial (Fig. 4). This record shows the generalised pattern of the response of biomass burning to rapid climate changes, and presumably the climatedriven changes in vegetation (see Fletcher et al., this volume; Takahara et al., this volume; Jiménez-Moreno et al., this volume; Heßler et al., this volume; Kershaw et al., this volume), associated with D-O cycles through the glacial. All of the GI except GI-11, GI-12, and GI-17, are marked by prominent increases in the composite charcoal concentration curves at or shortly after the warming event. There are other peaks in the composite curve that occur at times other than the D-O warming events: 
some of these are associated with cool intervals (e.g. before and after GI-18), but some of these correspond to unnamed warming events, such as those at $30.7 \mathrm{ka}$ and 69.4 ka. There are prominent troughs in the composite curve corresponding to each of HS (Fig. 4) and at the beginning of the Younger Dryas chronozone.

The general response of biomass burning as represented by the composite global record of fire regime can be seen in the superposed epoch plots for the charcoal and NGRIP oxygen isotope data (Fig. 5). The specific shape of the abrupt warming at the beginning of the GI, most rapid cooling that defines the GS and the more gradual cooling at the onsets of the HS are shown by the thin stepped lines in Figs. 5A, 5C and $5 \mathrm{E}$, respectively. The majority of the warming takes place within a single 20 -year sampling interval, the cooling within 200 years and within 500 years in case of the HS. The impact of smoothing (as has been done to construct the charcoal composite curve) is shown by the blue lines in Figs. 5A, 5C and 5E. The smoothing broadens the peaks and troughs in the SEA curves, such that the abrupt warming or cooling appears to begin a few hundred years earlier in the smoothed curves than in the unsmoothed curves. Nevertheless, the SEA curves for the smoothed oxygen-isotope data reflect a similar overall structure to the composite events as do the SEA curves for the unsmoothed data.

These plots show a strong non-linear correlation between biomass burning and temperature, characterised by a general increase in biomass burning during warming (Fig. 5A and B) and a decrease in biomass burning during cooling (Fig. 5C and D). Although biomass burning decreases markedly during the HS, the start of this decrease occurs well before the start of the cooling registered in the NGRIP oxygen isotope curve (Fig. 5E and F). However, this lead is not apparent during the D-O 
cooling events which suggests that it is simply an artefact of defining the start of HS using ages defined by Sánchez-Goñi and Harrison (this volume) which are slightly different from the start of decrease of temperature of NGRIP. Note that the charcoal SEA summary curves do not exactly match the corresponding oxygen-isotope SEA curves, as they would be expected to do if biomass burning as represented by charcoal were a proxy for the temperature variations represented by the Greenland oxygenisotope data. Instead, the comparison of the SEA curves show that biomass burning increases rapidly during D-O warming events, and reaches a peak at nearly the same time as temperature. In contrast, at the onset of the GS and HS, biomass burning decreases significantly and then returns to "background" levels while temperatures remain low (Figs. 5C and D; 5E and F). There is a significant peak in biomass burning corresponding to the D-O warming events, lagging the actual timing of the event by ca 100-200 years, roughly the same span that the smoothed oxygen-isotope data lags the unsmoothed data (Fig. 5B). The SEA curve lies outside of the confidence band at the onset of the GI and so there is evidence for a significant increase in biomass burning accompanying abrupt warming throughout MIS 2-4. During cooling events, biomass burning shows a significant trough ca 0-100 years after the onset of the start of the most rapid cooling of the GS (Fig. 5D), peaking ca 200 years after the onset of the cooling phase in case of the HS (Fig. 5F).

\section{Discussion}

This is a first attempt to document changes in global fire regimes during the glacial. Despite inter-site variability in the registration of changes in biomass burning, the 
composite record shows millennial-scale variability in fire regimes consistent with a response to D-O climate variability and concomitant changes in vegetation. Some records show a clear record of this variability, while others appear to register only some of the D-O cycles.

There are comparatively few charcoal records which cover the last glacial, and fewer which were sampled at sufficiently high resolution to allow diagnosis of millennialscale variability. The dating control on these records, particularly for MIS 4 and the first part of MIS 3 is, in general, poor - for the majority of records (60; see Table 1), the age model is based on extrapolation from available radiocarbon dates. In a small number of cases ( 3 records), other radiometric methods or luminescence dates were used to extend the age model. The age models for charcoal records from marine cores are principally based on radiometric methods and marine isotope stratigraphy. Orbital tuning of grain-size records was used to date the three cores from China. We have made no attempt to tune radiometrically-dated records to match the Greenland record nor have we converted existing orbitally-tuned age models to the GICC05 timescale. It is therefore encouraging that it is possible to extract a composite record and that this record shows millennial-scale variability throughout the glacial.

The most complete records of D-O variability in fire regimes are from analyses of charcoal in marine sediment cores. These records likely sample a larger source area than most terrestrial records (Lynch et al., 2007). Nevertheless, where it is possible to make comparisons with terrestrial charcoal records (see e.g. Moss and Kershaw, 2000) they appear to show similar patterns of change within the uncertainties of the chronology. Our analyses show that marine and terrestrial records show similar and 
coherent millennial-scale variability. Marine records have several distinct advantages for the analysis of long-term and millennial-scale variability in fire regimes: they are quasi-continuous and thus more likely to yield extremely long records, and agemodelling is made easier because of the existence of isotopic measurements on the same samples. Unfortunately, many fewer marine cores have been analysed for charcoal than for pollen (see e.g. Table 1).

The available long records show that the incidence of biomass burning was lower during the glacial than during the Eemian and the Holocene, supporting the idea of a strong relationship between temperature and fire regimes. This is also supported by the fact that globally biomass burning was higher during MIS 3 than MIS 2. These relationships are consistent with the finding that biomass burning was low during the last glacial maximum and the deglaciation, and higher (though more spatially variable) during the Holocene (Power et al., 2008; Daniau, Tinner et al., in prep.). The dominance of the temperature signal on biomass burning at glacial-interglacial timescales is unsurprising, given that colder climates are in general drier because of the Clausius-Clapeyron relationship (Clausius, 1865). Colder, drier conditions would reduce vegetation productivity and thus the availability of fuel for burning. As climate warms, and hence the global hydrological cycle becomes more vigorous, vegetation productivity would increase leading to an increase in fuel and fire.

A strong relationship between biomass burning and temperature, as recorded in the Greenland ice core, is apparent within the glacial. Global biomass burning is, in general, higher during GI and lower during GS. However, this signal is most marked in Europe. The composite biomass burning record presented here does not show the 
antiphasing apparent between the Greenland and Antarctic ice core records (EPICA Community Members, 2006). This does not appear to be due to a paucity of southern hemisphere charcoal records, but could reflect the distribution of these records given that some southern hemisphere climate regimes are strongly linked to northern hemisphere temperature variations through the thermohaline circulation (Clark et al.. 2002). Conversely, it may reflect problems with the lack of tie points to constrain the age models for sites in the tropics and southern extratropics.

Intervals of coolings associated with the end of D-O events and with HS showed an initial fire decline lasting 100-200 years followed then by slow increase of fire to levels similar to pre-cooling fire regimes. The long records also confirm that rapid warming during the glacial is accompanied by a marked increase in biomass burning. Observed changes in fire regime occur rapidly and lags D-O warming events by ca 100-200 years. Sanchez-Goni et al. (2009) have shown a similar time lag between D$\mathrm{O}$ warming and vegetation changes in southwestern Europe. The association between rapid warming and increases in biomass burning seen during the glacial has also been observed during the last deglaciation. Marlon et al. (2009) studied changes in fire regime across North America during the last glacial-interglacial transition and demonstrated that the rapid warming at the termination of the Younger Dryas chronozone was marked by increases in both the incidence of fires (registered by charcoal peaks), and the overall level of biomass burning. They did not attempt to quantify whether there was a lag between the warming and the change in the fire regime, but none is apparent in their composite curves. The objectively identified times of change in the trend of charcoal influx over the interval were indistinguishable from the beginning and end of the Younger-Dryas chronozone, however, which 
suggests little lag. According to Marlon et al. (2009), the rapid cooling at the onset of the Younger Dryas was associated with a moderate increase in biomass burning, but that increase could also be associated with the warming at $13.2 \mathrm{ka}$ following the InterAllerød Cool Period. One might expect to see an increase in biomass burning associated with the apparently very rapid cooling that marks the transition from GI to GS in some of the shorter D-O cycles (e.g. D-O 6). We have not explored this possibility, largely because the existing records do not have sufficient sampling resolution during these short cooling events (see Fig. 3) but this would be an issue worth exploring by re-sampling existing cores. Overall, the specific changes in biomass burning across the Younger Dryas chronozone described by Marlon et al. (2009) appear replicated by the multiple instances of abrupt warming and cooling present in the longer records analyzed here.

Both fire regime and vegetation (see Fletcher et al., this volume; Takahara et al., this volume; Jiménez-Moreno et al., this volume; Heßler et al., this volume; Kershaw et al., this volume) records show a clear response to D-O climate variability. The signal in both is clearest in the northern extratropics, and more muted in the tropics and southern hemisphere (see Heßler et al., this volume; Kershaw et al., this volume). The similarities between the two types of record open up the possibility that changes in fire regime are not caused directly by changes in climate but rather are modulated through climate-induced changes in vegetation. There are several ways in which changes in vegetation can affect the fire regime. Firstly, changes in climate affect vegetation productivity, leading to increases/decreases in the availability of fuel. Increased productivity during intervals of rapid climate warming, for example, could explain the observed increase in biomass burning particularly in regions which were 
fuel-limited (see e.g. van der Werf et al., 2008). Climate changes also lead to changes in the relative abundance of different plant functional types (PFTs), and thus produce differential mortality amongst these PFTs. This could also affect the amount of fuel available. When the change in climate is sufficiently large, there may be wholesale shifts in biomes. Transitions to biomes which are more open or characterised by firepromoting species (e.g. savannas or grasslands: Bond et al., 2005) could lead to increases in biomass burning. Biome transitions are characteristic of glacialinterglacial transitions, but can also occur during D-O cycles (see Fletcher et al., this volume).

Increases in biomass burning both on glacial-interglacial timescales and during D-O cycles are linked to either shifts from open to forest vegetation (see e.g. Fletcher et al., this volume) or increases in tree abundance (see e.g. Takahara et al., this volume). Under modern conditions, reductions in forest cover and the creation of more open vegetation would generally lead to an increase in fire (van der Werf et al., 2008). This suggests that the changes in fire regime during the glacial are more likely to be related to changes in productivity. Both the globally cold and dry conditions and the low $\mathrm{CO}_{2}$ concentration during the glacial limit productivity. We suggest that the climate changes that gave rise to vegetation shifts during the D-O warming events and GI would also have increased productivity overall, leading to increased fuel availability and hence more fire. Similarly, decreased fire in response to rapid cooling is a consequence of decreased fuel loads because of decreased vegetation productivity. The reasons for a return of fire to levels similar to pre-cooling fire regimes during DO cooling events or HS are less clear. Vegetation responses to sufficiently large and rapid cooling may include forest die-back, which would create conditions for 
increased fire.

One motivation for focusing on palaeofire regimes is to examine the relationships between climate, vegetation and fire when human influence on fire regimes is assumed to have been negligible. However, there have been speculations that the emergence of Modern Humans was associated with extensive use of fire (McBrearty and Brooks, 2000). Furthermore, it has explicitly been claimed that Aboriginal colonization of Australia around ca 45ka led to a major change in biomass burning (Kershaw, 1986; Kershaw et al., 2006). Modern humans arrived in Europe around ca $40 \mathrm{ka}$, but detailed analyses of charcoal records from western Europe show no changes in biomass burning over this interval (Daniau et al., in rev.) nor do the other European records included in this synthesis show a change in fire regime at this time. We also find no evidence of a significant shift in biomass burning in Australia around ca $45 \mathrm{ka}$ - again a result which is consistent with the increasing number of analyses of individual pollen and charcoal records from Australasia which show no significant change in fire regimes at the time of initial colonization (e.g. Stevenson and Hope, 2005; Dodson et al., 2005).

\section{Future perspectives}

This paper is a first attempt to synthesise charcoal records covering the last glacial and to explore changes in global fire regimes during a period characterised by millennial-scale climate variability and rapid warming events. Some interesting features have emerged from these analyses, but it is clear that the extant records provide fewer answers than questions. 
There are comparatively few records: our analyses are based on an order-ofmagnitude fewer sites than were used for analyses of the past 21 ka (Power et al., 2008; Daniau and Tinner et al., in prep). A significant increase in the number of records would be required to derive statistically robust results at a regional scale, results that would permit us to examine the possibility of differential responses to outof-phase climate changes between the northern and southern hemispheres (see Blunier et al., 1998; EPICA Community Members, 2006). The increasing interest in charcoal records from marine cores (see e.g. Beaufort et al., 2003; Thevenon et al., 2004; Daniau et al., 2007; 2009) is driving the production of more long records. Further expansion of the number of records could be achieved by exploiting the large number of archived marine cores that cover the last glacial. However, this should be accompanied by systematic studies of paired terrestrial and marine records, to determine at what scale the marine cores homogenise geographic differences in fire regimes.

Comparatively few of the charcoal records have been sampled at sub-millennial resolution. This precludes analysis of phenomena which have been studied during the more recent past (see e.g. Marlon et al., 2009), such as the abrupt changes in biomass burning that accompany equally abrupt changes in climate, or the consideration of multiple hypotheses for explaining particular features in charcoal records (e.g. Marlon et al., 2008). It would be interesting, for example, to see if there is a short-term increase in biomass burning at the transitions marking the onsets of GSs in those D-O cycles which are marked by a decrease in temperature in 20-60 years (e.g. D-O 6). This could be done by augmenting the sampling resolution for existing cores, but new 
high-resolution studies of specific D-O cycles would certainly be worthwhile.

Chronological control beyond the limits of radiocarbon dating is always problematic (Sirocko et al., 2007). In the case of charcoal records from marine sites, direct correlation of isotopic records with the Greenland isotope record is possible. Unfortunately, oxygen isotope records from lake sites cannot be used in this way because they are affected by changes in multiple climate factors (Roberts et al., 2008). Tephras can be used to synchronise records from within a specific region (Lowe et al., 2001); however, this still leaves the issue of precise dating and correlation with other regions open. Luminescence techniques provide a mechanism for dating older sediments, but are subject to large error margins and have not proved particularly successful on the lacustrine sediments (see e.g. Thomas et al., 2003) from which most of the terrestrial charcoal records are obtained. However, it is possible that better results could be obtained using the newly-developed single-grain multiple aliquot techniques (Roberts et al., 2003; Roberts, 2007), and these approaches should certainly be tried in order to improve the chronological control on charcoal records. Orbital tuning techniques have been used to date charcoal records from the Chinese Loess Plateau (Wang et al., 2005). However, without independent means of dating, the use of orbital tuning in this way precludes any attempt to investigate leads and lags in the relationship between rapid climate changes and fire (see e.g. Kohfeld and Harrison, 2003). It is clear that many extant charcoal records would benefit from better dating, including the use of multiple dating techniques, although this may still not provide a complete solution to the problem of improving the chronology of long records. 
We have speculated that changes in vegetation productivity may have been implicated in bringing about the observed changes in fire regime during the D-O cycles. Palaeoenvironmental data document what has happened in the past (Kohfeld and Harrison, 2000), and provoke this kind of speculation. Regional syntheses of vegetation data during the last glacial, such as those presented by Fletcher et al.(this volume); Takahara et al.(this volume); Jiménez-Moreno et al.(this volume); Heßler et al.(this volume); Kershaw et al.(this volume), will allow a more rigorous comparison between fire and vegetation records than is currently possible. However, disentangling the direct effects of climate, of changes in productivity, and changes in vegetation type on fire regimes requires modelling of the coupled climate-vegetationfire system. With the advent of fully dynamic vegetation-fire models (Lenihan and Neilson, 1998; Thonicke et al., 2001; Venevsky et al., 2002; Prentice et al., 2007), exploration of the relative importance of different mechanisms in driving changes in fire regimes through comparing carefully-designed experiments with observations now becomes possible. This approach has been used, for example, to quantify the relative impact of the direct effects of low $\mathrm{CO}_{2}$ and of climate changes on glacial vegetation (Harrison and Prentice, 2003). Vegetation-fire models have been used to examine the consequences of LGM climate changes on fire regimes (Thonicke et al., 2005). Similar experiments could be run using output from climate model simulations of the D-O cycles (see e.g. Kageyama et al., this volume).

Palaeoenvironmental databases are a useful tool for exploring many facets of past climate changes (see Harrison, 2007). Our analyses of fire regimes during the last glacial were greatly facilitated by the existence of the GPWG charcoal database. Continued development of this database will provide more opportunities for the kind 
of exploratory work we have done here. In conjunction with databases documenting changes in other aspects of the palaeoenvironment, most particularly vegetation changes, analyses of the charcoal records will provide insights into the relationships between climate, vegetation and fire, and ultimately a better understanding of the mechanisms of past climate changes.

\section{Acknowledgements}

This article is a contribution to the QUAVIDA working group of the ARC-NZ Network for Vegetation Function and to the Global Palaeofire Working Group (GPWG) of the International Geosphere-Biosphere Project Cross-Project Initiative on Fire. The GPWG is supported by the UK Natural Environment Research Council's

QUEST (Quantifying Uncertainty in the Earth System) programme. Data analysis was supported by the QUEST-DESIRE project (SPH), and by the US National Science Foundation Paleoclimatology Program (ATM 0714146, PJB). ALD is supported by a QUEST International Research Fellowship. We thank our colleagues in the GPWG who have made these analyses possible through their contributions to the GPWG Global Charcoal Database. We thank Masa Kageyama, Andrew Scott, Pierre Friedlingstein and Maria-Fernanda Sánchez-Goñi for their valuable comments which greatly improved this manuscript.

\section{References}

Alessio, A., Allegri, L., Calderoni, G., Cortesi, C., Dai Pra, G., De Rita, D., Follieri, M., Improta, S., Magri, D., Narcisi, B., Petrone, V., Sadori, L., 1986. ${ }^{14} \mathrm{C}$ dating, geochemical features, faunistic and pollen analyses of the uppermost 10 
m core from Valle di Castiglione (Rome, Italy). Geologica Romana 25, 287308.

Allan, R., Lindsay, J., 1998. Past climates of Australasia. In: Hobbs, J. E., Lindesay, J. A.Bridgman, H. A. (Eds.), Climates of the Southern Continents: Present, Past and Future. John Wiley, Chichester, pp. 207-247.

Anshari, G., Kershaw, A. P., Van der Kaars, S., 2001. A Late Pleistocene and Holocene pollen and charcoal record from peat swamp forest, Lake Sentarum Wildlife Reserve, West Kalimantan, Indonesia. Palaeogeography, Palaeoclimatology, Palaeoecology 171, 213-228.

Archibald, S., Roy, D. P., van Wilgen, B. W., Scholes, R. J., 2008. What limits fire? An examination of drivers of burnt area in Southern Africa. Global Change Biology, 10.1111/j.1365-2486.2008.01754.x.

Athens, J. S., Ward, J., 1999. The late Quaternary of the western Amazon: climate, vegetation and humans. Antiquity 280 (73), 287-302.

Aucour, A.-M., Hillaire-Marcel, C., Bonnefille, R., 1994. Late Quaternary biomass change from 13C measurments in a highland peatbog from equatorial Africa (Burundi). Quaternary Research 41, 225-233.

Beaufort, L., de Garidel-Thoron, T., Linsley, B., Oppo, D., Buchet, N., 2003. Biomass burning and oceanic primary production estimates in the Sulu Sea area over the last $380 \mathrm{kyr}$ and the East Asian Monsoon Dynamics. Marine Geology 201, 53-65.

Behling, H., 1997. Late Quaternary vegetation, climate and fire history from the tropical mountain region of Morro de Itapeva, SE Brazil. Palaeogeography, Palaeoclimatology, Palaeoecology 129, 407-422.

Behling, H., Lichte, M., 1997. Evidence of dry and cold climatic conditions at glacial times in tropical southeastern Brazil. Quaternary Research 48, 348-358.

Behling, H., Pillar, V. D., Orloci, L., Bauermann, S. G., 2004. Late Quaternary Araucaria forest, grassland (campos), fire and climate dynamics, studied by high-resolution pollen, charcoal and multivariate analysis of the Cambara do Sul core in southern Brazil. Palaeogeography, Palaeoclimatology, Palaeoecology 203, 277-297.

Bird, M. I., Cali, J. A., 2002. A revised high-resolution oxygen-isotope chronology for ODP-668B: implications for Quaternary biomass burning in Africa. Global and Planetary Change 33, 73-76.

Black, M. P., Mooney, S. D., Martin, H. A., 2006. A >43 000 year vegetation and fire history from Lake Baraba, New South Wales, Australia. Quaternary Science Reviews 25, 3003-3016.

Blunier, T., Chappellaz, J., Schwander, J., Dällenbach, A., Stauffer, B., Stocker, T. F., Raynaud, D., Jouzel, J., Clausen, H. B., Hammer, C. U., Johnsen, S. J., 1998. Asynchrony of Antarctic and Greenland climate change during the last glacial period. Nature 394, 739-743.

Bond, G., Broecker, W., Johnsen, S., McManus, J., Labeyrie, L., Jouzel, J., Bonani, G., 1993. Correlations between climate records from North Atlantic sediments and Greenland ice. Nature 365, 143-147.

Bond, W. J., Keeley, J. E., 2005. Fire as a global "herbivore": the ecology and evolution of flammable ecosystems. Trends in Ecology and Evolution 20, 387-394. 
Bond, W. J., Woodward, F. I., Midgley, G. F., 2005. The global distribution of ecosystems in a world without fire. New Phytologist 165, 525-538.

Bonnefille, R., Riollet, G., Buchet, G., Icole, M., Lafont, R., Arnold, M., Jolly, D., 1995. Glacial/Interglacial record from intertropical Africa, high resolution pollen and carbon data at Rusaka, Burundi. Quaternary Science Reviews 14, 917-936.

Bowman, D. M. J. S., Balch, J. K., Artaxo, P., Bond, W. J., Carlson, J. M., Cochrane, M. A., D’Antonio, C. M., DeFries, R. S., Doyle, J. C., Harrison, S. P., Johnston, F. H., Keeley, J. E., Krawchuk, M. A., Kull, C. A., Marston, J. B., Moritz, M. A., Prentice, I. C., Roos, C. I., Scott, A. C., Swetnam, T. W., van der Werf, G. R., Pyne, S. J., 2009. Fire in the Earth System. Science 324, 481-484.

Builth, H., Kershaw, A. P., White, C., Roach, A., Hartney, L., mcKenzie, M., Lewis, T., Jacobsen, G., 2008. Environmental and cultural change on the Mt Eccles lava-flow landscapes of southwest Victoria, Australia. The Holocene 18, 413-424.

Burney, D. A., 1987. Late Quaternary stratigraphic charcoal records from Madagascar. Quaternary Research 28, 274-280.

Bush, M. B., Oliveira, P. E., 2006. The rise and fall of the refugial hypothesis of Amazonian speciation: a paleoecological perspective. Biota Neotropica 6 (1), doi: 10.1590/S1676-06032006000100002.

Carcaillet, C., Almquist, H., Asnong, H., Bradshaw, R. H. W., Carrión, J. S., Gaillard, M.-J., Gajewski, K., Haas, J. N., Haberle, S. G., Hadorn, P., Müller, S. D., Richard, P. J. H., Richoz, I., Rösch, M., Sánchez Goñi, M. F., von Stedingk, H., Stevenson, A. C., Talon, B., Tardy, C., Tinner, W., Tryterud, E., Wick, L., Willis, K. J., 2002. Holocene biomass burning and global dynamics of the carbon cycle. Chemosphere 49, 845-863.

Chalson, J. M., 1991. The Late Quaternary vegetation and climatic history of the Blue Mountains, N.S.W., Australia. PhD Thesis, UNSW, Sydney, Australia

Clark, P. U., Pisias N. G., Stocker T. F. Weaver A. J., 2002. The role of the thermohaline circulation in abrupt climate change. Nature 415, 863-869.

Clausius, R., 1865. The Mechanical Theory of Heat - with its Applications to the Steam Engine and to Physical Properties of Bodies, John van Voorst, 1 Paternoster Row, London.

Colhoun, E. A., Pola, J. S., Barton, C. E., Heijnis, H., 1999. Late-Pleistocene vegetation and climate history of Lake Selina, western Tasmania. Quaternary International 57 (8), 5-23.

D'Costa, D. M., 1997. The Reconstruction of Quaternary Vegetation and Climate on King Island, Bass Strait, Australia. PhD Thesis, Monash University, Monash

Daniau, A.-L., Sánchez-Goñi, M. F., Beaufort, L., Laggoun-Defarge, F., Loutre, M.-F., Duprat, J., 2007. Dansgaard-Oeschger climatic variability revealed by fire emissions in southwestern Iberia. Quaternary Science Reviews 26, 13691383.

Daniau, A.-L., Sánchez-Goñi, M. F., Duprat, J., 2009. Last glacial fire regime variability in western France inferred from microcharcoal preserved in core MD04-2845, Bay of Biscay. Quaternary Research 71 (3), 385-396.

DeBano, L. F., Neary, D. G., Ffolliott, P. F., 1998. Fire Effects on Ecosystems. John Wiley and Sons, New York. 
Dodson, J. R., Robinson, M., Tardy, C. T., 2005. Two fine-resolution Pliocene charcoal records and their bearing on pre-human fire frequency in southwestern Australia. Austral Ecology 30, 592-599.

Donders, T. H., Wagner, F., Dilcher, D. L., Visscher, H., 2005. Mid- to late-Holocene El Nino-Southern Oscillation dynamics reflected in the subtropical terrestrial realm. Proceedings of the National Academy of Sciences 102 (31), 10904-10908.

Dupont, L. M., Behling, H., Kim, J.-H., 2008. Thirty thousand years of vegetation development and climate change in Angola (Ocean Drilling Program Site 1078). Climate of the Past 4, 107-124.

Edney, P. A., Kershaw, A. P., De Deckker, P., 1990. A late Pleistocene and Holocene vegetation and environmental record from Lake Wangoom, Western Plains of Victoria, Australia. Palaeogeography, Palaeoclimatology, Palaeoecology 80, 325-343.

EPICA Community Members, 2006. One-to-one hemispheric coupling of millennial polar climate variability during the last glacial. Nature 444, 195-198.

Field, J. H., Dodson, J. R., Prosser, I. P., 2002. A late Pleistocene vegetation history from the Australian semi-arid zone. Quaternary Science Reviews 21 (8), 1023-1037.

Grimm, E. C., Jacobson, G. L., W.A. Watts, J., Hansen, B. C. S., Maasch, K. A., 1993. A 50,000-year record of climate oscillations from Florida and its temporal correlation with the Heinrich events. Science 261, 198-200.

Haberle, S. G., Ledru, M.-P., 2001. Correlations among charcoal records of fires from the past 16,000 years in Indonesia, Papua New Guinea, and Central and South America. Quaternary Research 55, 97-104.

Harle, K. J., Heijnis, H., Chisari, R., Kershaw, A. P., Zoppi, U., Jacobsen, G., 2002. A chronology for the long pollen record from Lake Wangoom, western Victoria (Australia) as derived from uranium/thorium disequilibrium dating. Journal of Quaternary Science 17 (7), 707-720.

Harrison, S. P., 2007. Data-model comparisons. In: Elias, S. A. (Eds.), Encyclopedia of Quaternary Science. Elsevier, Amsterdam, pp. 1894-1907.

Harrison, S. P., Prentice, I. C., 2003. Climate and CO2 controls on global vegetation distribution at the last glacial maximum: analysis based on palaeovegetation data, biome modelling and palaeoclimate simulations. Global Change Biology 9, 983-1004.

Heusser, C. J., 1990. Ice age vegetation and climate of subtropical Chile. Palaeogeography, Palaeoclimatology, Palaeoecology 80 (2), 107-127.

Hope, G. S., 1996. History of Nothofagus in New Guinea and New Caledonia. In: Veblen, T. T. (Eds.), The Ecology and Biogeography of Nothofagus Forest. pp. 257-270.

Hope, G. S., 1998. Early fire and forest change in the Baliem Valley, Irian Jaya, Indonesia. Journal of Biogeography 25 (3), 453-461.

Hope, G. S., 2001. Environmental change in the Late Pleistocene and later Holocene at Wanda site, Soroako, South Sulawesi, Indonesia. Palaeogeography, Palaeoclimatology, Palaeoecology 171 (3-4), 129-145.

Hope, G. S., Pask, J., 1998. Tropical vegetational change in the Late Pleistocene of New Caledonia. Palaeogeography, Palaeoclimatology, Palaeoecology 142, $1-21$. 
Hu, F. S., Brubaker, L. B., Gavin, D. G., Higuera, P. E., Lynch, J. A., Rupp, T. S., Tinner, W., 2006. How climate and vegetation influence the fire regime of the Alaskan boreal biome: the Holocene perspective. Mitigation and Adaptation Strategies for Global Change 11, 829-846C, doi: 10.1007/s11027-005-9015-4.

Inoue, J., Takahara, H., Yoshikawa, S., Inouchi, Y., 2001. Reconstruction of fire history during the last 130 ka by analysis of microscopic charcoal in Lake Biwa sediment. The Quaternary Research 40, 97-104.

Kershaw, A. P., 1986. Climatic change and Aboriginal burning in north-east Australia during the last two glacial/interglacial cycles. Nature 322, 4749.

Kershaw, A. P., McKenzie, G. M., Porch, N., Roberts, R. G., Brown, J., Heijnis, H., Orr, M. L., Jacobsen, G., Newall, P. R., 2007. A high-resolution record of vegetation and climate through the last glacial cycle from Caledonia Fen, southeastern highlands of Australia. Journal of Quaternary Science 22 (5), 481-500.

Kershaw, P., van der Kaars, S., Moss, P., Opdyke, B., Guichard, F., Rule, S., Turney, C., 2006. Environmental change and the arrival of people in the Australian region. Before Farming 1 (2), http://www.waspress.co.uk/journals/beforefarming//journal 20061/.

Kohfeld, K. E., Harrison, S. P., 2000. How well can we simulate past climates ? Evaluating the models using global palaeoenvironmental data sets. Quaternary Science Reviews 19, 321-346.

Kohfeld, K. E., Harrison, S. P., 2003. Glacial-interglacial changes in dust deposition on the Chinese Loess Plateau. Quaternary Science Reviews 22, 1859-1878.

Kukla, G. J., Bender, M. L., de Beaulieu, J.-L., Bond, G., Broecker, W. S., Cleveringa, P., Gavin, J. E., Herbert, T. D., Imbrie, J., Jouzel, J., Keigwin, L. D., Knudsen, K.-L., McManus, J. F., Merkt, J., Muhs, D. R., Müller, H., Poore, R. Z., Porter, S. C., Seret, G., Shackleton, N. J., Turner, C., Tzedakis, P. C., Winograd, I. J., 2002. Last interglacial climates. Quaternary Research 58, 2-13.

Lavorel, S., Flannigan, M. D., Lambin, E. F., Scholes, M. C., 2007. Vulnerability of land systems to fire: Interactions among humans, climate, the atmosphere, and ecosystems. Mitigation and Adaptation Strategies for Global Change 12, 33-53.

Lenihan, J. M., Neilson, R. P., 1998. Simulating broad-scale fire severity in a dynamic global vegetation model. Northwest Science 72, 91-103.

Longmore, M. E., 1997. Quaternary Palynological Records from Perched Lake Sediments, Fraser Island, Queensland, Australia: Rainforest, Forest History and Climatic Control. Australian Journal of Botany 45 (3), 507 526.

Lowe, J. J., Hoek, W. Z., INTIMATE group, 2001. Inter-regional correlation of palaeoclimatic records for the Last Glacial-Interglacial Transition: a protocol for improved precision recommended by the INTIMATE project group. Quaternary Science Reviews 20, 1175-1187.

Lynch, A. H., Beringer, J., Kershaw, P., Marshall, A., Mooney, S., Tapper, N., Turney, C., Van Der Kaars, S., 2007. Using the paleorecord to evaluate climate and fire interactions in Australia. Annual Review of Earth and Planetary Sciences 35, 215-239. 
Magri, D., 1999. Late-Quaternary vegetation history at Lagaccione near Lago di Bolsena (central Italy). Review of Palaeobotany and Palynology 106, 171208.

Magri, D., 2008. Two long micro-charcoal records from central Italy. Proceedings of the Third International Meeting of Anthracology. BAR International Series, Cavallino - Lecce (Italy).

Marchant, R. D., Taylor, D., Hamilton, A., 1997. Late Pleistocene and Holocene history at Mubwindi Swamp, southeast Uganda. Quaternary Research 47 (3), 316-328.

Marlon, J., Bartlein, P. J., Whitlock, C., 2006. Fire-fuel-climate linkages in the northwestern USA during the Holocene. The Holocene 16, 1059-1071.

Marlon, J. R., Bartlein, P. J., Carcaillet, C., Gavin, D. G., Harrison, S. P., Higuera, P. E., Joos, F., Power, M. J., Prentice, I. C., 2008. Climate and human influences on global biomass burning over the past two millennia. Nature Geoscience 1, 697-702.

Marlon, J. R., Bartlein, P. J., Walsh, M. K., Harrison, S. P., Brown, K. J., Edwards, M. E., Higuera, P. E., Power, M. J., Anderson, R. S., Briles, C., Brunelle, A., Carcaillet, C., Daniels, M., Hu, F. S., Lavoie, M., Long, C., Minckley, T., Richard, P. J. H., Scott, A. C., Shafer, D. S., Tinner, W., Umbanhowar Jr., C. E., Whitlock, C., 2009. Wildfire responses to abrupt climate change in North America. Proceedings of the National Academy of Sciences, doi: 10.1073/ pnas.0808212106.

McBrearty, S., Brooks, A. S., 2000. The revolution that wasn't: a new interpretation of the origin of modern human behavior. Journal of Human Evolution 39, 453-563.

McKenzie, G. M., 1997. The late Quaternary vegetation history of the southcentral highlands of Victoria, Australia:1. Sites above 900m. Australian Journal of Ecology 22, 19-36.

McKenzie, G. M., Kershaw, A. P., 2000. The last glacial cycle from Wyelangta, the Otway region of Victoria, Australia. Palaeogeography, Palaeoclimatology, Palaeoecology 155, 177-193.

Moss, P. T., Kershaw, A. P., 2000. The last glacial cycle from the humid tropics of northeastern Australia: comparison of a terrestrial and marine record. Palaeogeography, Palaeoclimatology, Palaeoecology 155, 155-176.

Mourguiart, P., Ledru, M.-P., 2003. Last Glacial Maximum in an Andean cloud forest environment (Eastern Cordillera, Bolivia). Geology 31 (3), 195-198.

Muscheler, R., Beer, J., 2006. Solar forced Dansgaard/Oeschger events. Geophysical Research Letters 33, doi: 10.1029/2006GL026779.

Newnham, R. M., Lowe, D. J., Giles, T. M., Alloway, B. V., 2007a. Vegetation and climate of Auckland, New Zealand, since ca 32,000 cal yr ago: support for an extended LGM. Journal of Quaternary Science 22, 517-534.

Newnham, R. M., Vandergoes, M. J., Hendy, C. H., Lowe, D. J., Preusser, F., 2007b. A terrestrial palynological record for the last two glacial cycles from southwestern New Zealand. Quaternary Science Reviews 26 (3-4), 517535.

North Greenland Ice Core Project Members, 2004. High resolution climate record of the Northern Hemisphere reaching into the last Glacial Interglacial Period. Nature 431, 147-151. 
Overpeck, J. T., Webb, R., 2000. Nonglacial Rapid Climate Events: Past and Future. Proceedings of the National Academy of Sciences of the United States of America 97, 1335-1338.

Penny, D., 2001. A 40,000 year palynological record from north-east Thailand; implications for biogeography and palaeo-environmental reconstruction. Palaeogeography, Palaeoclimatology, Palaeoecology 171, 97-128.

Power, M. J., Marlon, J., Ortiz, N., Bartlein, P. J., Harrison, S. P., Mayle, F. E., Ballouche, A., Bradshaw, R. H. W., Carcaillet, C., Cordova, C., Mooney, S., Moreno, P. I., Prentice, I. C., Thonicke, K., Tinner, W., Whitlock, C., Zhang, Y., Zhao, Y., Ali, A. A., Anderson, R. S., Beer, R., Behling, H., Briles, C., Brown, K. J., Brunelle, A., Bush, M., Camill, P., Chu, G. Q., Clark, J., Colombaroli, D., Connor, S., Daniau, A.-L., Daniels, M., Dodson, J., Doughty, E., Edwards, M. E., Finsinger, W., Foster, D., Frechette, J., Gaillard, M.-J., Gavin, D. G., Gobet, E., Haberle, S., Hallett, D. J., Higuera, P. E., Hope, G., Horn, S., Inoue, J., Kaltenreider, P., Kennedy, L., Kong, Z. C., Larsen, C., Long, C. J., Lynch, J. A., Lynch, E. A., McGlone, M., Meeks, S., Mensing, S., Meyer, G., Minckley, T., Mohr, J., Nelson, D. M., New, J., Newnham, R., Noti, R., Oswald, W., Pierce, J., Richard, P. J. H., Rowe, C., Sanchez Goñi, M. F., Shuman, B. J., Takahara, H., Toney, J., Turney, C., Urrego-Sanchez, D. H., Umbanhowar, C., Vandergoes, M., Vanniere, B., Vescovi, E., Walsh, M., Wang, X., Williams, N., Wilmshurst, J., Zhang, J. H., 2008. Changes in fire regimes since the Last Glacial Maximum: an assessment based on a global synthesis and analysis of charcoal data. Climate Dynamics 30, 887-907.

Power, M. J., Marlon, J. R., Bartlein, P. J., Harrison, S. P., in press. Fire History and the Global Charcoal Database: a new tool for hypothesis testing and data exploration. Palaeogeography, Palaeoclimatology, Palaeoecology.

Prager, M. H., Hoenig, J. M., 1992. Can we determine the significance of key-event effects on a recruitment time series?--a power study of superposed epoch analysis. Transactions of the American Fisheries Society 121, 123-131.

Prentice, I. C., Bondeau, A., Cramer, W., Harrison, S. P., Hickler, T., Lucht, W., Sitch, S., Smith, B., Sykes, M. T., 2007. Dynamic vegetation modelling: quantifying terrestrial ecosystem responses to large-scale environmental change. In: Canadell, J., Pitelka, L. F.Pataki, D. (Eds.), Terrestrial Ecosystems in a Changing World. Springer-Verlag, pp. 175-192.

Roberts, H. M., 2007. Assessing the effectiveness of the double-SAR protocol in isolating a luminescence signal dominated by quartz. Radiation Measurements 42, 1627-1636.

Roberts, H. M., Muhs, D. R., Wintle, A. G., Duller, G. A. T., Bettis III, E. A., 2003. Unprecedented last glacial mass accumulation rates determined by luminescence dating of loess from western Nebraska. Quaternary Research 59, 411-419.

Roberts, N., Jones, M. D., Benkaddour, A., Eastwood, W. J., Filippi, M. L., Frogley, M. R., Lamb, H. F., Leng, M. J., Reed, J. M., Stein, M., Stevens, L., Valero-Garcés, B., Zanchetta, G., 2008. Stable isotope records of Late Quaternary climate and hydrology from Mediterranean lakes: the ISOMED synthesis. Quaternary Science Reviews 27, 2426-2441.

Salgado-Labouriau, M. L., Casseti, V., Ferraz-Vicentini, K. R., Martin, L., Soubiès, F., Suguio, K., Turcq, B., 1997. Late Quaternary vegetational and climatic 
changes in cerrado and palm swamp from Central Brazil.

Palaeogeography, Palaeoclimatology, Palaeoecology 128 (1-4), 215-226.

Sánchez Goñi, M.F., Landais, A., Cacho, I., Duprat, J., Rossignol, L., 2009.

Contrasting intrainterstadial climatic evolution between high and middle North

Atlantic latitudes: A close-up of Greenland Interstadials 8 and 12.

Geochemistry, Geophysics, Geosystems 10 (4), 1-16.

Scott, L., 2000. Microscopic charcoal in sediments: Quaternary fire history of the grassland and savanna regions in South Africa. Journal of Quaternary Science 17 (1), 77-86.

Shichi, K., Takahara, H., Krivonogov, S. K., Bezrukova, E. V., Kashiwaya, K., Takehara, A., Nakamura, T., 2009. Late Pleistocene and Holocene vegetation and climate records from Lake Kotokel, central Baikal region. Quaternary International 205, 98-110.

Singh, G., Kershaw, A. P., Clark, R., 1981. Quaternary vegetation and fire history in Australia. In: Gill, A. M., Groves, R. A.Noble, I. R. (Eds.), Fire and the Australian Biota. Australian Academy of Science, Canberra, pp. 23-54.

Singh, Y. P., Badruddin, 2006. Statistical considerations in superposed epoch analysis and its applications in space research. Journal of Atmospheric and Solar-Terrestrial Physics 68, 803-813.

Sirocko, F., Claussen, M., Litt, T., Sánchez-Goni, M. F., Lohmann, G., et al, 2007. Chronology and climate forcing of the last four interglacials. In: Sirocko, F., Claussen, M., Sanchez Goñi, M. F.Litt, T. (Eds.), The climate of past interglacials. Elsevier.

Stevenson, J., Hope, G. S., 2005. A comparison of late Quaternary forest changes in New Caledonia and northeastern Australia. Quaternary Research 64, 372383.

Sun, X. J., Li, X., Chen, H. C., 2000. Evidence for natural fire and climate history since $37 \mathrm{ka}$ BP in the northern part of the South China Sea. Science in China (Series D) 43 (5), 487-493.

Thevenon, F., Bard, E., Williamson, D., Beaufort, L., 2004. A biomass burning record from the West Equatorial Pacific over the last 360 kyr: methodological, climatic and anthropic implications. Paleogeography, Paleoclimatology, Paleoecology 213, 83-99.

Thomas, P. J., Murray, A. S., Sandgren, P., 2003. Age limit and age underestimation using different OSL signals from lacustrine quartz and polymineral fine grains. Quaternary Science Reviews 22, 1139-1143.

Thonicke, K., Prentice, C. I., Hewitt, C., 2005. Modeling glacial-interglacial changes in global fire regimes and trace gas emissions. Global Biogeochemical Cycles 19 (GB3008), doi: 10.1029/2004GB002278.

Thonicke, K., Venevsky, S., Sitch, S., Cramer, W., 2001. The role of fire disturbance for global vegetation dynamics: coupling fire into a Dynamic Global Vegetation Model. Global Ecology and Biogeography 10, 661-678.

Van der Kaars, S., De Deckker, P., 2002. A late Quaternary pollen record from deep sea core Fr10/95, GC17 offshore Cape Range Peninsula, northwestern Western Australia. Review of Palaeobotany and Palynology 120, 17-39.

van der Kaars, W. A., Wang, X., Kershaw, A. P., Guichard, F., Setiabudi, D. A., 2000. A late Quaternary palaeoecological record from the Banda Sea, Indonesia: patterns of vegetation, climate and biomass burning in Indonesia and 
northern Australia. Palaeogeography, Palaeoclimatology, Palaeoecology 155, 135-153.

van der Werf, G. R., Randerson, J. T., Giglio, L., Gobron, N., Dolman, A. J., 2008. Climate controls on the variability of fires in the tropics and subtropics. Global Biogeochemical Cycles 22 (GB3028), doi:10.1029/2007GB003122.

Vandergoes, M. J., Newnham, R. M., Preusser, F., Hendy, C. H., Lowell, T. V., Fitzsimons, S. J., Hogg, A. G., Kasper, H. U., Schlüchter, C., 2005. Regional insolation forcing of Late Quaternary climate change in the Southern Hemisphere. Nature 436, 242-245.

Venevsky, S., Thonicke, K., Sitch, S., Cramer, W., 2002. Simulating fire regimes in human-dominated ecosystems: Iberian Peninsula case study. Global Change Biology 8, 984-998.

Verardo, D. J., Ruddiman, W. F., 1996. Late Pleistocene charcoal in tropical Atlantic deep-sea sediments: climatic and geochemical significance. Geology 24 (9), 855-857.

Wang, X., Peng, P. A., Ding, Z. L., 2005. Black carbon records in Chinese Loess Plateau over the last two glacial cycles and implications for paleofires. Palaeogeography, Palaeoclimatology, Palaeoecology 223, 9-19.

Wang, X., van der Kaars, S., Kershaw, P., Bird, M., Jansen, F., 1999. A record of fire, vegetation and climate through the last three glacial cycles from Lombok Ridge core G6-4, eastern Indian Ocean, Indonesia. Palaeogeography, Palaeoclimatology, Palaeoecology 147, 241-256.

Watts, W. A., Hansen, B. C. S., 1988. Environment of Florida in the late Wisconsin and Holocene. Telford Press, Caldwell, N.J.

Whitlock, C., Bartlein, P. J., 2004. Holocene fire activity as a record of past environmental change. Development in Quaternary Science 1, 479-490.

Wolff, E. W., Chappellaz, J., Blunier, T., Rasmussen, S. O., Svensson, A., Millennialscale variability during the last glacial: the ice core record.

Wooler, M. J., Swain, D. L., Ficken, K. J., Agnew, A. D. Q., Street-Perrott, F. A., Eglington, G., 2003. Late Quaternary vegetation changes around Lake Rutundu, Mount Kenya, East Africa: evidence from grass cuticles, pollen and stable carbon isotopes. Journal of Quaternary Science 18 (1), 3-15. 
Table 1: Charcoal records from the GCD_V2 covering all or part of the last glacial (MIS 4, 3 and 2). The sites are classified according to sampling resolution: high $(>1$ sample per ka) or low $(<1$ sample per ka).

\begin{tabular}{|c|c|c|c|c|c|c|c|c|c|c|c|}
\hline $\begin{array}{l}\text { ID_site } \\
\text { (GCD_V2) }\end{array}$ & Site name & $\begin{array}{l}\text { Latitude } \\
\text { (decimal } \\
\text { degrees) }\end{array}$ & $\begin{array}{l}\text { Longitude } \\
\text { (decimal } \\
\text { degrees) }\end{array}$ & $\begin{array}{l}\text { Elevation } \\
\text { (m) }\end{array}$ & Site type & $\begin{array}{l}\text { Presence of } \\
\text { Eemian (E) } \\
\text { and/or } \\
\text { Holocene (H) }\end{array}$ & $\begin{array}{l}\text { Glacial } \\
\text { coverage (MIS) }\end{array}$ & $\begin{array}{l}\text { Dating control during } \\
\text { MIS 4-2 }\end{array}$ & $\begin{array}{l}\text { Sampling } \\
\text { resolution } \\
\text { during MIS 4- } \\
2\end{array}$ & Reference & $\begin{array}{l}\text { Pollen } \\
\text { record } \\
\text { available }\end{array}$ \\
\hline 59 & Siberia 93-1 & -17.8333 & -64.7189 & 2920 & terrestrial & $\mathrm{H}$ & 2 , part of 3 & $10{ }^{14} \mathrm{C}$ dates & High & $\begin{array}{l}\text { Mourguiart and } \\
\text { Ledru, } 2003\end{array}$ & yes \\
\hline 83 & Morro de Itapeva & -22.7833 & -45.5733 & 1850 & terrestrial & $\mathrm{H}$ & 2, part of 3 & $3{ }^{14} \mathrm{C}$ dates & Low & Behling, 1997 & yes \\
\hline 85 & Catas Altas & -20.0833 & -43.3667 & 755 & terrestrial & $-\cdots-$ & 2,3 & $6{ }^{14} \mathrm{C}$ dates & Low & $\begin{array}{l}\text { Behling and Lichte, } \\
1997\end{array}$ & yes \\
\hline 90 & Cambara do Sul & -29.0525 & -50.1011 & 1040 & terrestrial & $\mathrm{H}$ & 2, part of 3 & $3{ }^{14} \mathrm{C}$ dates & High & Behling et al., 2004 & yes \\
\hline 95 & 17940 core & 20.11667 & 117.3833 & -1727 & marine & $\mathrm{H}$ & 2 , part of 3 & 8 AMS dates & Low & Sun et al., 2000 & yes \\
\hline
\end{tabular}




\begin{tabular}{|c|c|c|c|c|c|c|c|c|c|c|c|}
\hline 109 & \begin{tabular}{|l} 
Lijiayuan section \\
\end{tabular} & 36.11667 & 104.8583 & 1850 & terrestrial & $\mathrm{E}, \mathrm{H}$ & $2,3,4$ & $\begin{array}{l}\text { Orbital grain size curves } \\
\text { tuning }\end{array}$ & High & Wang et al., 2005 & no \\
\hline 110 & Lingtai section & 35.00917 & 107.5092 & 1400 & terrestrial & $\mathrm{E}, \mathrm{H}$ & $2,3,4$ & $\begin{array}{l}\text { Orbital grain size curves } \\
\text { tuning }\end{array}$ & High & Wang et al., 2005 & no \\
\hline 111 & Weinan section1 & 34.06667 & 109 & 650 & terrestrial & $\mathrm{E}, \mathrm{H}$ & $2,3,4$ & $\begin{array}{l}\text { Orbital grain size curves } \\
\text { tuning }\end{array}$ & High & Wang et al., 2005 & no \\
\hline 120 & Crominia & -17.2785 & -49.4181 & 710 & terrestrial & $\mathrm{H}$ & 2 , part of 3 & $3{ }^{14} \mathrm{C}$ dates & High & $\begin{array}{l}\text { Salgado-Labouriau } \\
\text { et al., } 1997\end{array}$ & yes \\
\hline 140 & Tagua Tagua & -34.5 & -71.1667 & 200 & terrestrial & $\mathrm{H}$ & 2 , part of 3 & $8{ }^{14} \mathrm{C}$ dates & High & Heusser, 1990 & yes \\
\hline 188 & Maxus-Core5 & -0.7 & -76.45 & 3 & terrestrial & $\mathrm{H}$ & 2, part of 3 & 1 AMS, $2{ }^{14} \mathrm{C}$ dates & Low & $\begin{array}{l}\text { Athens and Ward, } \\
1999\end{array}$ & no \\
\hline 233 & $\begin{array}{l}\text { Banda Sea Core SHI- } \\
9014\end{array}$ & -5.76667 & 126.9667 & -3163 & marine & $\mathrm{E}, \mathrm{H}$ & $2,3,4$ & $\begin{array}{l}7 \text { AMS, } 3 \text { tie-points } \\
\text { based on marine isotope } \\
\text { stratigraphy }\end{array}$ & Low & $\begin{array}{l}\text { van der Kaars et al., } \\
2000\end{array}$ & yes \\
\hline 234 & ODP Site 820 & -16.6333 & 146.3 & -280 & marine & $\mathrm{E}, \mathrm{H}$ & $2,3,4$ & $\begin{array}{l}3 \text { AMS dates, } 1 \text { tie-point } \\
\text { based on MIS boundary }\end{array}$ & High & $\begin{array}{l}\text { Moss and Kershaw, } \\
2000\end{array}$ & yes \\
\hline 236 & Lake George & -35.0656 & 149.4181 & 673 & terrestrial & $\begin{array}{l}1 \text { sample in } \mathrm{E} \text {, } \\
\mathrm{H}\end{array}$ & $2,3,4$ & $3{ }^{14} \mathrm{C}$ dates & High & Singh et al., 1981 & yes \\
\hline 237 & Lake Wangoom 20m & -38.35 & 142.6 & 100 & terrestrial & $\mathrm{H}$ & 2, part of 3 & $3{ }^{14} \mathrm{C}$ dates & High & Edney et al., 1990 & yes \\
\hline
\end{tabular}




\begin{tabular}{|c|c|c|c|c|c|c|c|c|c|c|c|}
\hline & Core & & & & & & & & & & \\
\hline 240 & $\begin{array}{l}\text { Tom Burns Missen } \\
\text { Core }\end{array}$ & -37.3833 & 145.8167 & 1075 & terrestrial & $\mathrm{H}$ & 2 , part of 3 & 1 date ${ }^{14} \mathrm{C}$ & Low & McKenzie, 1997 & yes \\
\hline 243 & $\begin{array}{l}\text { Lake Baraba } \\
\text { Thirlmere Lakes }\end{array}$ & -34.2342 & 150.5397 & 305 & terrestrial & $\mathrm{H}$ & 2,3 & 1 AMS date & High & Black et al., 2006 & yes \\
\hline 244 & Redhead Lagoon & -32.9944 & 151.7208 & 65 & terrestrial & $\mathrm{H}$ & $2,3,4$ & $4{ }^{14} \mathrm{C}$ dates & High & $\begin{array}{l}\text { Williams, N. } \\
\text { (unpublished) }\end{array}$ & no \\
\hline 248 & Cuddie Springs & -30.3795 & 147.3117 & 127 & terrestrial & E, $\mathrm{H}$ & $2,3,4$ & 14 AMS dates, 1 OSL & Low & Field et al., 2002 & yes \\
\hline 250 & Core Fr10/95-GC-17 & -22.0458 & 113.5018 & -1093 & marine & $\mathrm{H}$ & 2, part of 3,4 & $\begin{array}{l}3 \text { AMS dates, } 4 \text { tie- } \\
\text { points based on marine } \\
\text { isotope stratigraphy }\end{array}$ & High & $\begin{array}{l}\text { Van der Kaars and } \\
\text { De Deckker, } 2002\end{array}$ & yes \\
\hline 252 & Penrith Lakes & -33.7139 & 150.6774 & 18 & terrestrial & $\mathrm{H}$ & 2 , part of 3 & $2{ }^{14} \mathrm{C}$ dates & Low & Chalson, 1991 & yes \\
\hline 323 & Sacred Lake & 0.045906 & 37.52885 & 2350 & terrestrial & $\mathrm{H}$ & 2 , part of 3 & $6{ }^{14} \mathrm{C}$ dates & Low & Scott, 2000 & no \\
\hline 348 & ODP-668B & -20.9269 & 4.77056 & -2693 & marine & E, H & $2,3,4$ & $\begin{array}{l}3 \text { tie-points based on } \\
\text { MIS boundary }\end{array}$ & Low & Bird and Cali, 2002 & no \\
\hline 349 & Pemerak Swamp & 0.7888 & 112.05 & 40 & terrestrial & $\mathrm{H}$ & 2 , part of 3 & 2 AMS dates, $1{ }^{14} \mathrm{C}$ date & Low & Anshari et al., 2001 & no \\
\hline 350 & Piston Core RC24-07 & -11.9167 & 1.35 & -3899 & marine & $\mathrm{H}, \mathrm{E}$ & $2,3,4$ & $\begin{array}{l}2 \text { tie-points based on } \\
\text { MIS boundary }\end{array}$ & High & $\begin{array}{l}\text { Verardo and } \\
\text { Ruddiman, } 1996\end{array}$ & no \\
\hline
\end{tabular}




\begin{tabular}{|c|c|c|c|c|c|c|c|c|c|c|c|}
\hline 351 & Rusaka Swamp & -3.43333 & 29.61667 & 2070 & terrestrial & $\mathrm{H}$ & 2, part of 3 & 1 date ${ }^{14} \mathrm{C}$ & Low & $\begin{array}{l}\text { Bonnefille et al., } \\
1995\end{array}$ & no \\
\hline 355 & Kashiru Swamp & $\begin{array}{l}-3.46667 \\
\end{array}$ & 29.56667 & 2240 & terrestrial & $\mathrm{H}$ & 2 , part of 3 & 2 AMS dates & Low & Aucour et al., 1994 & yes \\
\hline 360 & Lake Rutundu & -0.04217 & 37.46488 & 3140 & terrestrial & $\mathrm{H}$ & 2 , part of 3 & 8 AMS dates & Low & Wooler et al., 2003 & yes \\
\hline 374 & Nong Pa Kho & 17.01 & 102.93 & 180 & terrestrial & $\mathrm{H}$ & 2 , part of 3 & 2 AMS dates & High & Penny, 2001 & yes \\
\hline 432 & Lake Pata & 0.266667 & -66.0667 & 300 & terrestrial & $\mathrm{H}$ & 2 , part of 3 & $4{ }^{14} \mathrm{C}$ dates, 7 AMS dates & High & $\begin{array}{l}\text { Bush and Oliveira, } \\
2006\end{array}$ & yes \\
\hline 437 & Galway Tarn & -43.4083 & 169.8733 & 130 & terrestrial & 3 samples in $\mathrm{H}$ & 2 , part of 3 & $\mathrm{n} / \mathrm{a}$ & High & $\begin{array}{l}\text { Vandergoes, M. } \\
\text { (unpublished) }\end{array}$ & no \\
\hline 438 & Okarito Pakihi & -43.2417 & 170.2167 & 70 & terrestrial & E, $\mathrm{H}$ & $2,3,4$ & 2 AMS, 2 TL & Low & $\begin{array}{l}\text { Newnham et al., } \\
\text { 2007b ; Vandergoes } \\
\text { et al., } 2005\end{array}$ & yes \\
\hline 450 & Mubwindi Swamp & -1.08333 & 29.75417 & 2100 & terrestrial & $\mathrm{H}$ & 2 , part of 3 & $5{ }^{14} \mathrm{C}$ dates, 1 AMS & Low & $\begin{array}{l}\text { Marchant et al., } \\
1997\end{array}$ & yes \\
\hline 451 & $\begin{array}{l}\text { Lake Biwa } \\
\text { Takashima-oki Core }\end{array}$ & 35.245 & 136.0538 & 85 & terrestrial & E, $\mathrm{H}$ & $2,3,4$ & $7{ }^{14} \mathrm{C}$ dates, 1 tephra & Low & Inoue et al., 2001 & yes \\
\hline 479 & Lac Suprin & -22.18 & 166.59 & 230 & terrestrial & - & 2, part of 3 & $4{ }^{14} \mathrm{C}$ dates & High & $\begin{array}{l}\text { Hope and Pask, } \\
1998\end{array}$ & yes \\
\hline
\end{tabular}




\begin{tabular}{|c|c|c|c|c|c|c|c|c|c|c|c|}
\hline 483 & Supulah Hill & -4.07 & 138.58 & 1580 & terrestrial & $\mathrm{H}$ & 2 , part of 3 & $2{ }^{14} \mathrm{C}$ dates & Low & Hope, 1998 & yes \\
\hline 484 & Wanda & -2.33 & 121.23 & 440 & terrestrial & $\mathrm{H}$ & 2 , part of 3 & $3{ }^{14} \mathrm{C}$ dates, $1 \mathrm{AMS}$ & Low & Hope, 2001 & yes \\
\hline 488 & Kohuora & -36.57 & 174.52 & 0 & terrestrial & $\mathrm{H}$ & 2 , part of 3 & $8{ }^{14} \mathrm{C}, 2 \mathrm{AMS}$ & Low & $\begin{array}{l}\text { Newnham et al., } \\
2007 \text { a }\end{array}$ & yes \\
\hline 542 & MD95-2042 & 37.75 & -10.1667 & -3146 & marine & $\mathrm{E}, \mathrm{H}$ & $2,3,4$ & $\begin{array}{l}16 \text { AMS, } 7 \text { tie-points of } \\
\text { planktonic } \delta^{18} \mathrm{O} \text { tuning, } \\
\text { IRD }\end{array}$ & High & Daniau et al., 2007 & yes \\
\hline 557 & Lake Tulane & 27.5862 & -81.5033 & 35 & terrestrial & $\mathrm{H}$ & 2 , part of 3 & $9{ }^{14} \mathrm{C}$ dates & Low & $\begin{array}{l}\text { Watts and Hansen, } \\
\text { 1988; Grimm et al., } \\
1993\end{array}$ & yes \\
\hline 560 & $\begin{array}{l}\text { Matsabory } \\
\text { Ampozalana }\end{array}$ & -12.5 & 49.15 & 0 & terrestrial & $-{ }^{----}$ & part of 2 and 3 & 4 dates ${ }^{14} \mathrm{C}$ & High & Burney, 1987 & no \\
\hline 597 & Allom Lake & -25.2333 & 153.1667 & 100 & terrestrial & $\mathrm{H}$ & Part of 3 & $5{ }^{14} \mathrm{C}$ dates & High & Donders et al., 2005 & yes \\
\hline 683 & Duliha bog & 51.51667 & 105 & NOTK & terrestrial & $\mathrm{H}$ & 2 , part of 3 & 5 AMS dates & Low & $\begin{array}{l}\text { Takahara, H. and } \\
\text { Krivonogov, S. } \\
\text { (unpublished data) }\end{array}$ & no \\
\hline 684 & Cheremushuka bog & 52.75 & 108.0833 & NOTK & terrestrial & $\mathrm{H}$ & 2 , part of 3 & 3 AMS dates & Low & Shichi et al., 2009 & yes \\
\hline 722 & Xere Wapo C & -22.29 & 166.97 & 220 & terrestrial & $\mathrm{H}$ & $2,3,4$ & 6 AMS dates & High & $\begin{array}{l}\text { Stevenson and } \\
\text { Hope, } 2005\end{array}$ & yes \\
\hline
\end{tabular}




\begin{tabular}{|c|c|c|c|c|c|c|c|c|c|c|c|}
\hline 733 & Lake Hordorli & -2.533 & 140.55 & 680 & terrestrial & $\mathrm{H}$ & 2,3, part of 4 & $5^{14} \mathrm{C}$ & Low & Hope, 1996 & yes \\
\hline 769 & Little Lake & 44.16802 & -123.584 & 703 & terrestrial & $\mathrm{H}$ & 2, part of 3 & 2 AMS dates & High & $\begin{array}{l}\text { Long, C., } \\
\text { (unpublished data) }\end{array}$ & yes \\
\hline 787 & Kosipe A & -8.4667 & 147.2 & 1960 & terrestrial & $\mathrm{H}$ & 2 , part of 3 & 2 AMS dates & Low & $\begin{array}{l}\text { Hope, G. } \\
\text { (unpublished data) }\end{array}$ & yes \\
\hline 788 & Kosipe C & -8.4667 & 147.2 & 1960 & terrestrial & $\mathrm{H}$ & 2 , part of 3 & 1 date ${ }^{14} \mathrm{C}$ & Low & $\begin{array}{l}\text { Hope, G. } \\
\text { (unpublished data) }\end{array}$ & yes \\
\hline 807 & Xere Wapo B & -22.29 & 166.97 & 220 & terrestrial & $\mathrm{E}, \mathrm{H}$ & $2,3,4$ & $1{ }^{14} \mathrm{C}$ date, 2 AMS & Low & $\begin{array}{l}\text { Hope and Pask, } \\
1998 ; \\
\text { Stevenson and } \\
\text { Hope, } 2005\end{array}$ & yes \\
\hline 808 & Xere Wapo D & -22.29 & 166.97 & 220 & terrestrial & $\mid---$ & 3,4 & 2 AMS dates & High & $\begin{array}{l}\text { Stevenson and } \\
\text { Hope, } 2005\end{array}$ & yes \\
\hline 819 & $\begin{array}{l}\text { Native Companion } \\
\text { Lagoon }\end{array}$ & -27.6754 & 153.4107 & 20 & terrestrial & $\mathrm{H}$ & 2 , part of 3 & 10 AMS & High & Chalson, 1991 & no \\
\hline 832 & Egg Lagoon & -39.65 & 143.95 & 20 & terrestrial & $\mathrm{E}, \mathrm{H}$ & $2,3,4$ & $\mathrm{n} / \mathrm{a}$ & Low & D'Costa, 1997 & yes \\
\hline 845 & Lagaccione & 42.56667 & 11.85 & 355 & terrestrial & $\mathrm{H}$ & $2,3,4$ & $\begin{array}{l}3{ }^{14} \mathrm{C} \text { dates, } 3 \text { AMS, } 1 \\
\text { POCO }\end{array}$ & High & $\begin{array}{l}\text { Magri, 1999; Magri, } \\
2008\end{array}$ & yes \\
\hline 846 & Valle di Castiglione & 41.725 & 12.75972 & 44 & terrestrial & $\mathrm{H}, \mathrm{E}$ & $2,3,4$ & $7{ }^{14} \mathrm{C}$ dates & High & Alessio et al., 1986; & yes \\
\hline
\end{tabular}




\begin{tabular}{|c|c|c|c|c|c|c|c|c|c|c|c|}
\hline & & & & & & & & & & Magri, 2008 & \\
\hline 849 & MD04-2845 & 45.35 & -5.2167 & -4175 & marine & $E$ & part of $2,3,4$ & $\begin{array}{l}17 \text { AMS dates, IRD, } \\
\text { POCO }\end{array}$ & High & Daniau et al., 2009 & yes \\
\hline 859 & Caledonia fen & -37.3333 & 146.7333 & 1280 & terrestrial & $\mathrm{E}, \mathrm{H}$ & $2,3,4$ & 9 AMS, 3 OSL & High & Kershaw et al., 2007 & yes \\
\hline 876 & Wyelangta & -38.6472 & 143.4614 & 450 & terrestrial & $\mathrm{E}, \mathrm{H}$ & $2,3,4$ & $1 \mathrm{POCO}$ & Low & $\begin{array}{l}\text { McKenzie and } \\
\text { Kershaw, } 2000\end{array}$ & yes \\
\hline 899 & Lake Selina & -41.8833 & 145.6 & 516 & terrestrial & $\mathrm{E}, \mathrm{H}$ & $2,3,4$ & $\begin{array}{l}1{ }^{14} \mathrm{C}, 2 \text { AMS, } 2 \text { tie- } \\
\text { points based on } \\
\text { correlation using } \square^{18} 0 \\
\text { and paleomag. }\end{array}$ & Low & Colhoun et al., 1999 & yes \\
\hline 900 & $\begin{array}{l}\text { Lombok Ridge Core } \\
\text { G6-4 }\end{array}$ & -10.7833 & 118.0667 & -3510 & marine & $\mathrm{E}, \mathrm{H}$ & $2,3,4$ & $\begin{array}{l}1 \text { AMS, } 3 \text { tie-points } \\
\text { based on MIS boundary }\end{array}$ & Low & Wang et al., 1999 & yes \\
\hline 901 & Lake Coomboo & -25.2195 & 153.1959 & 90 & terrestrial & $\mathrm{E}, \mathrm{H}$ & $2,3,4$ & $3{ }^{14} \mathrm{C}$ & Low & Longmore, 1997 & yes \\
\hline 902 & Lynchs Crater & -17.3667 & 145.7 & 760 & terrestrial & $\mathrm{H}$ & $2,3,4$ & ${ }^{2{ }^{14} \mathrm{C}}$ & High & Kershaw, 1986 & yes \\
\hline 1021 & Lake Surprise & -38.0612 & 141.9223 & 93 & terrestrial & $\mathrm{H}$ & 1,2, part of 3 & $5{ }^{14} \mathrm{C}$ dates & Low & Builth et al., 2008 & yes \\
\hline 1057 & Tyrendarra Swamp & -38.1986 & 141.7626 & 13 & terrestrial & $\mathrm{H}$ & Part of 3 & 3 AMS dates & High & Builth et al., 2008 & yes \\
\hline $1101-1102$ & $\begin{array}{l}\text { Lake Wangoom } \\
\text { LW87 (Top Core and }\end{array}$ & -38.35 & 142.6 & 100 & terrestrial & $\mathrm{E}, \mathrm{H}$ & $2,3,4$ & 1 AMS, 2 UTh & Low & Harle et al., 2002 & yes \\
\hline
\end{tabular}




\begin{tabular}{|c|c|c|c|c|c|c|c|c|c|c|c|}
\hline & bottom core) & & & & & & & & & & \\
\hline
\end{tabular}


Fig. 1: Location of marine and terrestrial sites with charcoal records covering all or part of the last glacial. The sites are classified according to sampling resolution: high ( $>1$ sample per ka) indicated by black circles, or low $(<1$ sample per ka) indicated by open circles (See Table 1).

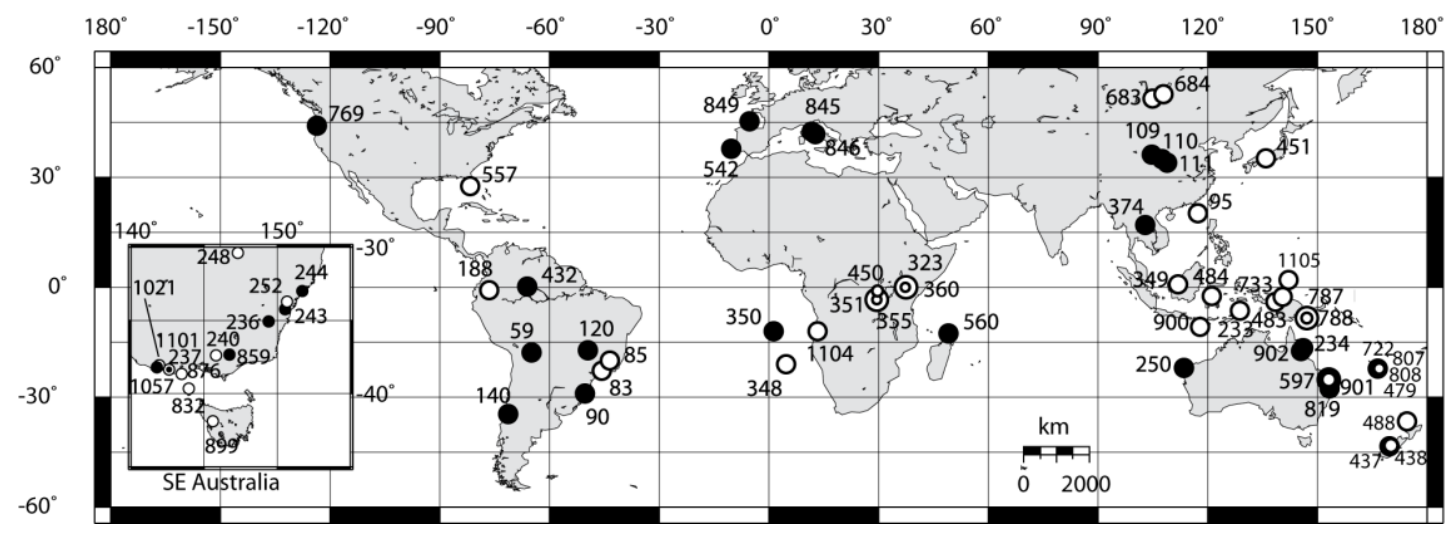


Fig. 2: Box plots of transformed (see text) charcoal data for (a) global, (b) northern hemisphere, and (c) southern hemisphere during the glacial compared to the Eemian and Holocene, and for MIS 4, 3 and 2. The lower and upper limits of the box represent the 25 th and 75 th percentiles, respectively.
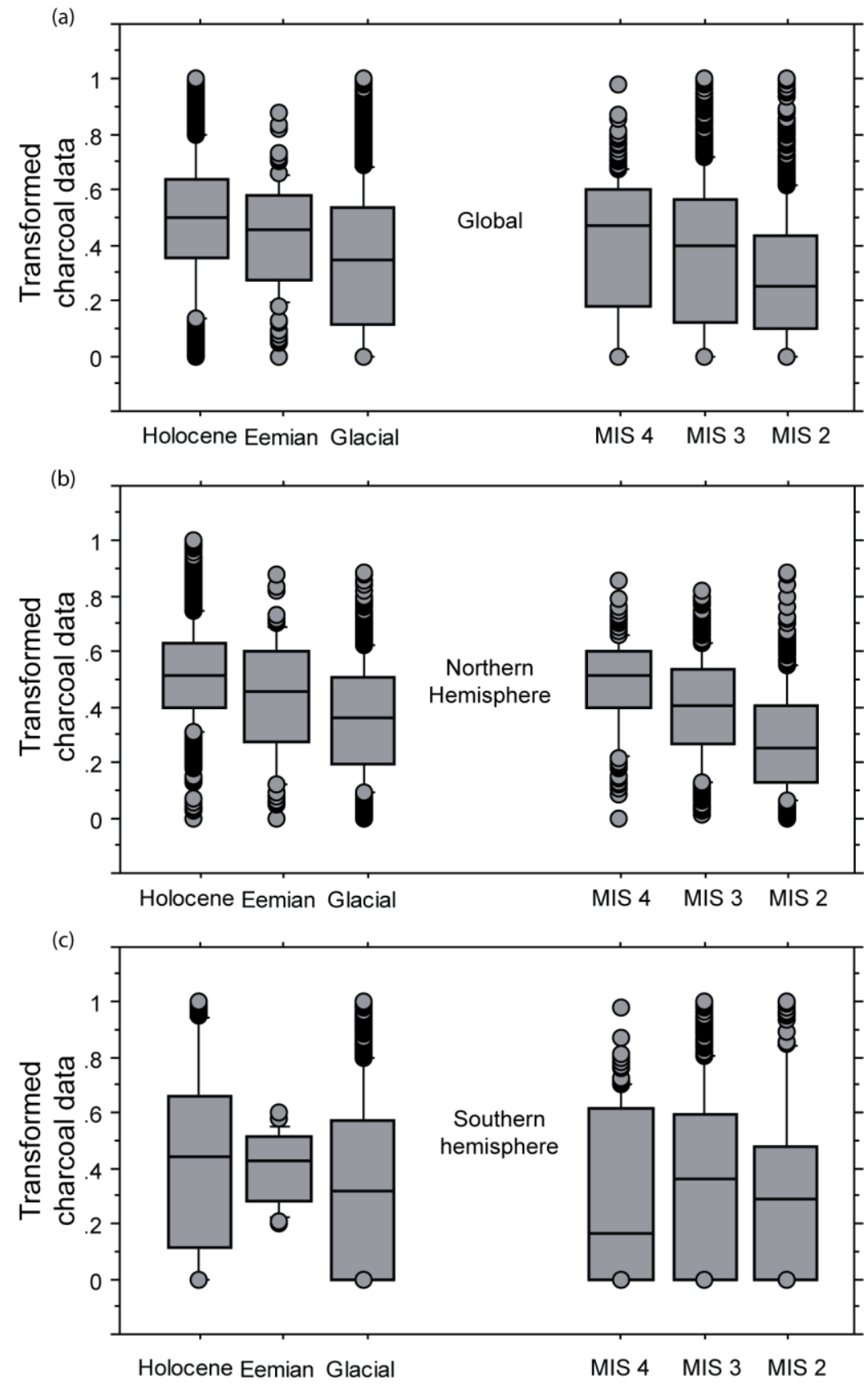
Fig. 3: Changes in transformed charcoal concentration/abundance for the 30 highresolution records covering the last glacial, arranged from north (top) to south (bottom). The sites are designated by their site number (see Table 1) and continent (North America: NAM; South America: SAM; Europe: EUR; Australasia: AUST; Africa: AFR; Asia: ASIA). Grey bands indicate MIS 2 and 4. The chronological position of the D-O warming events, using the GICC05 chronology (Wolff et al., this volume), are shown by red lines and the number of the corresponding GIs is shown. 


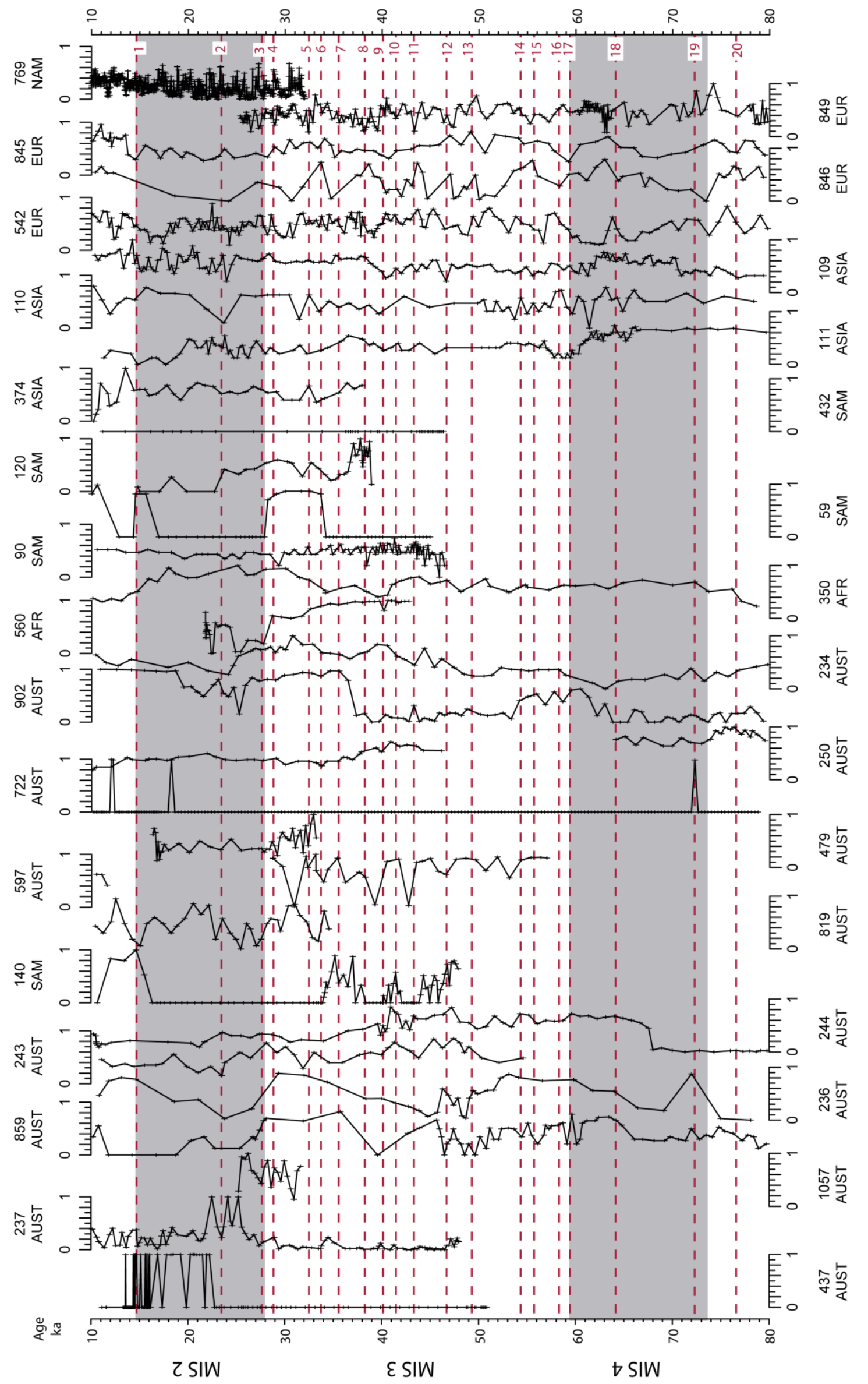


Fig. 4: Reconstruction of global biomass burning through the glacial based on the 30 high-resolution sites. Charcoal data are summarized using a lowess curve (middle) with a 400-yr half-window width (red), and to represent the long-term trend, a 2000year window width (gray). The number of individual charcoal records that contribute to the summary curves is plotted at the bottom. For comparison with the charcoal curve, the 20-yr sampling resolution NGRIP record (age yr b1950) is shown, along with a 400-yr smoothed curve (blue).

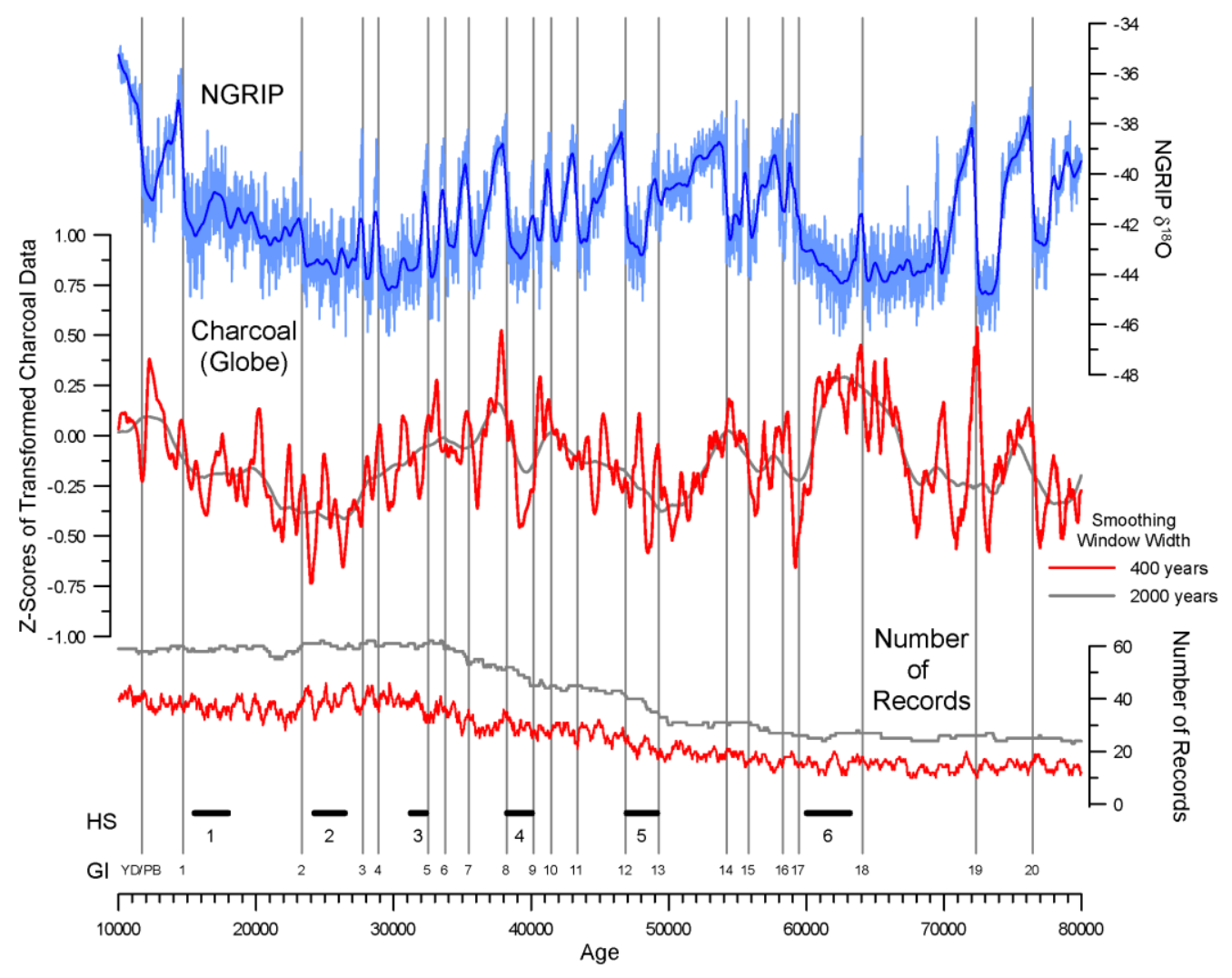


Table 2: Start of D-O warming events, most rapid cooling and Heinrich stadials following Sánchez-Goñi and Harrison (this volume), Wolff et al.(this volume) and this study. Ages are given in ka b1950.

\begin{tabular}{|c|c|c|c|}
\hline $\begin{array}{l}\text { Start of which } \\
\text { GI }\end{array}$ & Start of GIs & $\begin{array}{l}\text { Start of most rapid } \\
\text { cooling }\end{array}$ & Start of HS \\
\hline 1 & 14.642 & 14.150 & \\
\hline 2 & 23.290 & 23.250 & HS $1=18.0$ \\
\hline 3 & 27.730 & 27.590 & HS $2=26.5$ \\
\hline 4 & 28.850 & 28.630 & \\
\hline 5 & 32.450 & 32.130 & HS $3=32.7$ \\
\hline 6 & 33.690 & 33.410 & \\
\hline 7 & 35.430 & 34.750 & \\
\hline 8 & 38.170 & 37.450 & \\
\hline 9 & 40.110 & 39.970 & HS $4=40.2$ \\
\hline 10 & 41.410 & 40.990 & \\
\hline 11 & 43.290 & 42.670 & \\
\hline 12 & 46.810 & 44.350 & \\
\hline 13 & 49.230 & 48.630 & HS $5=50.0$ \\
\hline 14 & 54.170 & $\mathrm{n} / \mathrm{a}$ & \\
\hline 15 & 55.750 & 55.410 & \\
\hline 16 & 58.230 & 56.650 & \\
\hline 17 & 59.390 & 58.590 & \\
\hline 18 & 64.045 & 63.850 & HS $6=63.2$ \\
\hline 19 & 72.280 & 70.970 & \\
\hline 20 & 76.400 & 74.270 & \\
\hline
\end{tabular}


Fig. 5: Superposed epoch analysis (SEA) composites illustrating changes in biomass burning associated with D-O warming event (A and B), D-O cooling event (C and D) and Heinrich Stadials (E and F) with $\mathrm{x}$-axis corresponding to time (before event on the right and after event on the left). The confidence intervals are given by MonteCarlo simulation using the timing of the 20 D-O warming events, 19 D-O cooling events and the 6 Heinrich Stadials. The NGRIP $\delta^{18}$ O SEA composite record for the DO cycles and Heinrich events is shown for comparison.

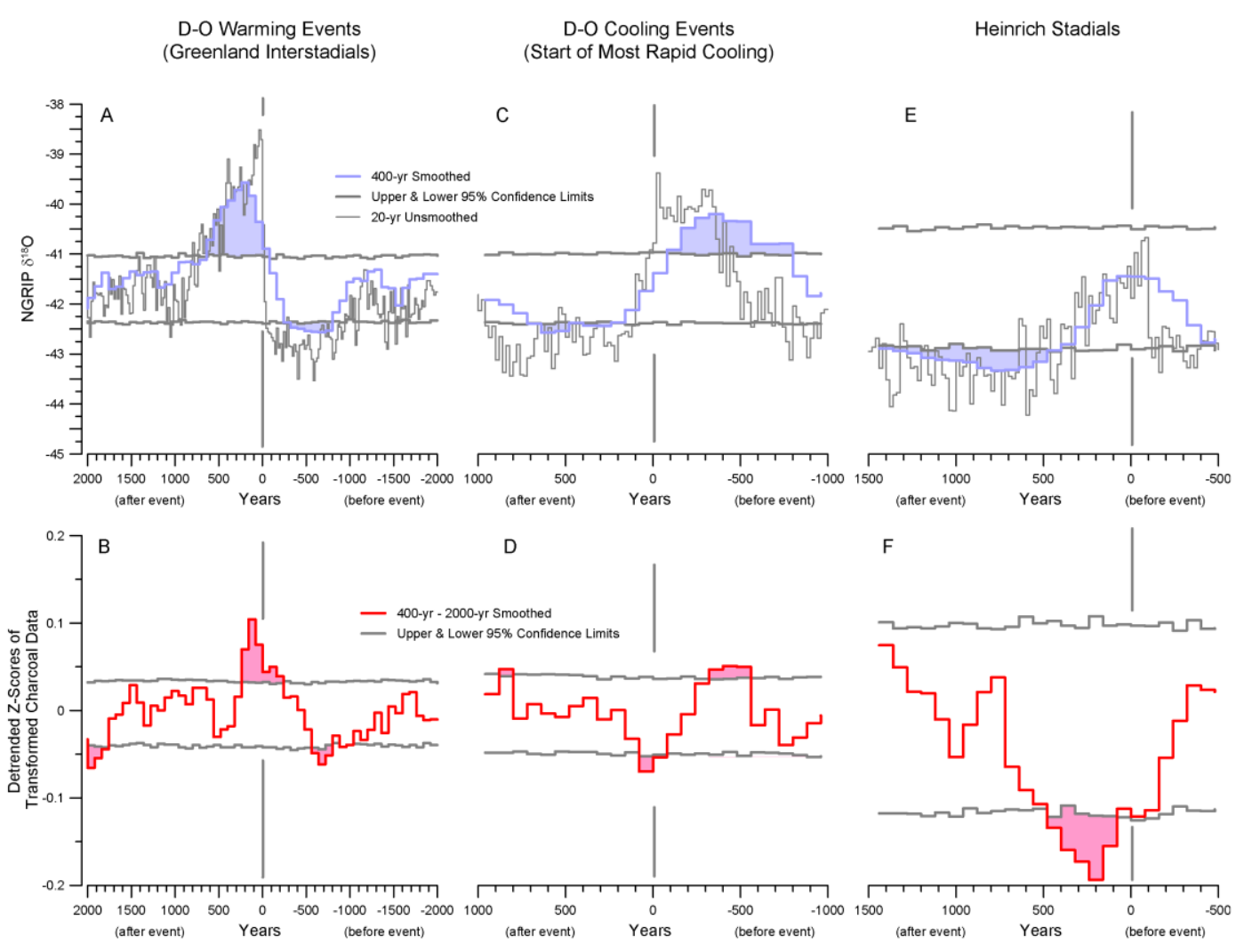

